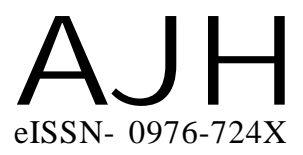

Article history :

Received : 10.05.2014

Revised : 09.10.2014

Accepted : 23.10.2014

Members of the Research Forum

Associated Authors:

${ }^{1}$ Department of Floriculture and

Landscaping, College of Agriculture,

Orissa University of Agriculture and

Technology, BHUBANESHWAR

(ODISHA) INDIA

Email : chitta.mohanty55@gmail.com

Author for correspondence :

\section{S.K. PATRA}

Department of Floriculture and

Landscaping, College of Agriculture,

Orissa University of Agriculture and

Technology, BHUBANESHWAR

(ODISHA) INDIA

Email : sailendra_patra@yahoo.co.in
THE ASIAN JOURNAL OF HORTICULTURE

Volume $9 \mid$ Issue 2 | Dec., 2014|352-355

Visit us -www.researchjournal.co.in

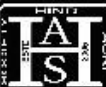

RESEARCH PAPER

DOI : 10.15740/HAS/TAJH/9.2/352-355

\title{
Variability studies in gladiolus
}

\section{S.K. PATRA AND C.R. MOHANTY ${ }^{1}$}

ABSTRACT : In the study of genetic variability, heritability and genetic advance in gladiolus, wide differences were found in mean performance of genotypes for almost all the characters. Variety Adagio possessed maximum plant height with highest number and width of leaves while Friendship White had the shortest height. Variety Jessica was the earliest in emergence of flower spike, showing colour of basal floret and opening of basal floret. Variety White Prosperity possessed maximum spike length, rachis length and number of florets with highest bloom life. Maximum range of variation was observed for length of spike whereas the minimum was recorded for spike diameter. Characters such as weight of corm exhibited maximum co-efficient of variation (GCV and PCV) coupled with high heritability and genetic advance as percentage of mean followed by number of florets per spike, diameter of corm, rachis length and difference between two florets which could be relied upon for effective selection and crop improvement in gladiolus.

KEY WORDS : Variability, Heritability, Genetic advance, GCV, PCV

HOW TO CITE THIS ARTICLE : Patra, S.K. and Mohanthy, C.R. (2014). Variability studies in gladiolus. Asian J. Hort., 9(2) : 352-355. 